\title{
Perbedaan Perkembangan Bahasa Anak Pra Sekolah yang Mengikuti dan Tidak Mengikuti PAUD
}

\author{
Yuliana Purnama Dewi ${ }^{1}$, Artika Nurrahima ${ }^{1, *}$ \\ ${ }^{1}$ Departemen Ilmu Keperawatan Fakultas Kedokteran, Universitas Diponegoro, Semarang, Indonesia \\ artikanurrahima@fk.undip.ac.id
}

\begin{abstract}
Background: Delay in language development can affect subsequent development in children. Research comparing language development of pre-school age children who participated and did not participated in PAUD had never been done before. The purpose of this study was to analyze differences in language development of pre-schoolers who attended Early Childhood Education (PAUD) and did not attend Early Childhood Education (PAUD).

Methods: This research was a quantitative research with comparative descriptive method. The sampling technique was proportionate random sampling and involved of 82 children in Bulusan Village, Tembalang District, Semarang City. Data analysis used Kolmogorov-Smirnov test.

Results: The results showed that the language development of pre-schoolers attending the early childhood was better than the non-attending pre-schoolers with p-value from non-parametric test Kolmogorov Smirnov (0.032) $<\alpha(0.005)$.

Conclusion: There are differences of preschool language development who attended and did not attend PAUD. Based on the results of the study, it is advisable for parents of children to provide stimulation appropriate to the stage of language development of children according to their age and to include children in PAUD.
\end{abstract}

Keywords: Kindegarten, Language development, Pre-school children

\begin{abstract}
Abstrak
Pendahuluan: Keterlambatan perkembangan bahasa dapat memengaruhi perkembangan selanjutnya pada anak. Belum pernah terdapat penelitian yang membandingkan perkembangan bahasa anak usia pra sekolah yang mengikuti dan tidak mengikuti PAUD. Tujuan penelitian ini adalah menganalisa perbedaan perkembangan bahasa anak usia prasekolah yang mengikuti Pendidikan Anak Usia Dini (PAUD) dan tidak mengikuti Pendidikan Anak Usia Dini (PAUD).

Metode: Penelitian ini merupakan penelitian kuantitatif dengan metode deskriptif komparatif. Teknik pengambilan sampel dengan metode proportionate random sampling dan melibatkan 82 anak PAUD di Kelurahan Bulusan, Kecamatan Tembalang, Kota Semarang menggunakan kuesioner perkembangan bahasa anak. Analisis bivariat menggunakan uji Kolmogorov-Smirnov.

Hasil: Hasil penelitian menunjukkan bahwa perkembangan bahasa anak prasekolah yang mengikuti PAUD hasilnya lebih baik daripada anak yang tidak mengikuti PAUD dengan $p$-value dari uji non parametrik Kolmogorov Smirnov yaitu $(0,032)<\alpha(0,005)$

Kesimpulan: Terdapat perbedaan perkembangan bahasa anak prasekolah yang mengikuti dan tidak mengikuti PAUD. Berdasarkan hasil penelitian, disarankan bagi orangtua anak untuk memberikan stimulasi yang sesuai tahap perkembangan bahasa anak sesuai usianya dan memasukkan anak ke PAUD.
\end{abstract}

Kata kunci: Anak pra sekolah, PAUD, Perkembangan bahasa 


\section{PENDAHULUAN}

Jumlah populasi anak usia prasekolah di Indonesia pada tahun 2017 terdapat 14.423.800 jiwa dan jumlah anak usia prasekolah yang mengikuti Pendidikan Anak Usia Dini (PAUD) sebanyak 5.885.851 jiwa (Kementerian Pemberdayaan Perempuan dan Perlindungan Anak RI 2015). Jumlah anak pada usia prasekolah yang cukup besar membutuhkan perhatian yang lebih terhadap pertumbuhan dan perkembangannya.

Anak pada masa prasekolah merupakan masa golden age untuk pertumbuhan otak anak, sehingga masa ini menentukan kualitas hidup anak dan menjadi peluang emas bagi keluarga untuk memberikan intervensi sebaik mungkin bagi anak (Soetjiningsih \& Ranuh, 2014). Tugas perkembangan bahasa anak menjadi salah satu komponen penting pada anak prasekolah dimana kemampuan berbahasa seorang anak adalah indikator keseluruhan dari perkembangan anak (Soetjiningsih \& Ranuh, 2014).Ketertinggalan dari perkembangan bahasa dan bicara juga menjadi salah satu indikator anak mengalami gangguan fungsi otak dan gangguan perkembangan kognitif sehingga anak memiliki intelegensi yang rendah (Tiel, 2007).

Jaringan otak anak yang banyak diberikan stimulasi akan berkembang mencapai $80 \%$ pada usia kurang dari 4 tahun, sebaliknya anak yang kurang diberikan stimulasi maka jaringan otak akan mengecil sehingga fungsi otak akan menurun yang menjadikan perkembangan anak menjadi terhambat (Dhieni, Fridani, Muis, \& Yarmi, 2014). Anak yang memiliki gangguan perkembangan bahasa mempunyai peluang lebih besar untuk mengalami ketakutan berlebihan dan gejala kecemasan saat bersosialisasi di usia remajanya (Browlnie, Bao, \& Beitchman, 2016).

Lingkungan pertama yang dekat dengan anak yaitu lingkungan keluarga dimana untuk pertama kalinya keluarga melakukan interaksi dengan anak untuk mengembangkan kemampuan anak sesuai tahap perkembangannya (Hati \& Lestari, 2016). Orang tua dengan pendidikan yang tinggi memiliki pengetahuan yang lebih baik mengenai tumbuh kembang anak dan orang tua yang sibuk bekerja memiliki waktu yang lebih sedikit dalam memberikan stimulus kepada anak (Mannani, 2017). Sehingga stimulasi dibutuhkan tidak hanya dari lingkungan keluarga namun membutuhkan rangsangan dari lingkungan lain.

Selain keluarga lingkungan tempat bermain anak juga menjadi stimulus yang bisa didapatkan secara formal dan non formal (Liadewi, 2010). Salah satu pendidikan non formal yang ada di Indonesia adalah pendidikan anak usia dini. PAUD yang ada di Indonesia memiliki kurikulum dari Peraturan Menteri Pendidikan Kebudayaan Republik Indonesia tahun 2014 salah satunya yaitu memuat program-program pengembangan yang mencakup bahasa dan tugas perkembangan lainnya (Kementerian Pendidikan dan Kebudayaan RI, 2015).

Fenomena yang ada Kelurahan Bulusan pada penilaian awal perkembangan bahasa yang sudah dilakukan pada beberapa anak prasekolah yaitu sebagian besar anak yang mengikuti PAUD memiliki perkembangan bahasa yang sesuai dan hasil untuk anak yang tidak mengikuti PAUD sebagian besar anak memiliki perkembangan bahasa yang sesuai namun ditemukan anak dengan perkembangan bahasa yang menyimpang. 
Penelitian sebelumnya terkait perkembangan bahasa anak usia pra sekolah dilakukan pada setting Taman Kanak-Kanak (TK) dan PAUD (Hidayah, Prabowo, \& Najmuna, 2013; Mulqiah, Santi, \& Lestari, 2017; Zaim, Mahfuddin, \& Rahmadi, 2016). Belum pernah terdapat penelitian yang membandingkan perkembangan bahasa anak usia pra sekolah yang mengikuti dan tidak mengikuti PAUD.

Tujuan dari penelitian ini adalah untuk mengetahui perbedaan perkembangan bahasa anak prasekolah yang mengikuti dan tidak mengukuti PAUD di Kelurahan Bulusan.

\section{METODE}

Penelitian ini menggunakan jenis penelitian kuantitaif dengan desain penelitian deskriptif komparatif. Teknik pengambilan sampel yang digunakan adalah probability sampling dengan metode proportionate random sampling. Jumlah sampel sebesar 82 responden terdiri dari kelompok yang mengikuti PAUD dan kelompok yang tidak mengikuti PAUD. Instrumen yang digunakan adalah kuesioner perkembangan bahasa anak yang dibuat oleh Mulqiah, Santi, dan Lestari, (2017). Analisis data menggunakan analisis univariat dan bivariat. Analisis bivariat menggunakan Uji Pearson Chi-Square yang di uji alternatif dengan Kolmogorov-Smirnov. Penelitian ini telah disetujui oleh Komisi Etik Penelitian Kesehatan Fakultas Kedokteran Universitas Diponegoro dan RSUP dr Kariadi Semarang dengan No. 441/EC/FK-RSDK/VII/2018.

\section{HASIL}

Tabel 1. Distribusi Frekuensi Perkembangan Bahasa Responden yang Mengikuti dan Tidak Mengikuti PAUD di Kelurahan Bulusan Juli $2018(n=82)$

\begin{tabular}{llcc}
\hline $\begin{array}{c}\text { Karakteristik } \\
\text { Responden }\end{array}$ & $\begin{array}{c}\text { Perkembangan } \\
\text { Bahasa Anak }\end{array}$ & Frekuensi & $\begin{array}{c}\text { Persentase } \\
(\mathbf{\%})\end{array}$ \\
\hline PAUD & Sesuai & 27 & 65,9 \\
& Meragukan & 14 & 34,1 \\
& Menyimpang & 0 & 0 \\
Tidak PAUD & Sesuai & 14 & 34,1 \\
& Meragukan & 18 & 43,9 \\
& Menyimpang & 9 & 22,0 \\
\hline Total & $\mathbf{4 1}$ & $\mathbf{1 0 0}$ \\
\hline
\end{tabular}

Tabel 1 menunjukkan bahwa dominasi perkembangan bahasa dari 41 responden yang mengikuti PAUD adalah sesuai yaitu sebanyak 27 orang $(65,9 \%)$ dan pada responden yang tidak mengikuti PAUD menunjukkan bahwa dominasi perkembangan bahasa meragukan yaitu sebanyak 18 responden $(43,9 \%)$.

Tabel 2 Komparasi Perkembangan Bahasa Anak Prasekolah yang Mengikuti dan Tidak Mengikuti PAUD di Kelurahan Bulusan Juli $2018(n=82)$

\begin{tabular}{lccc}
\hline \multicolumn{1}{c}{ Variabel } & n & $\begin{array}{c}\text { Std. } \\
\text { Deviation }\end{array}$ & p-value \\
\hline $\begin{array}{l}\text { Perkembangan } \\
\text { Bahasa Anak }\end{array}$ & 41 & & \\
PAUD & & & \\
$\begin{array}{l}\text { Perkembangan } \\
\text { Bahasa Anak } \\
\text { Non PAUD }\end{array}$ & 41 & & \\
\hline
\end{tabular}


Tabel 2 menunjukkan hasil dalam uji Kolomogorov-smirnov adalah p-value $(0.032)<\alpha(0,05)$. Hal ini menunjukkan adanya perbedaan antara perkembangan bahasa anak yang mengikuti dan tidak mengikuti PAUD di Kelurahan Bulusan.

\section{PEMBAHASAN}

Hasil penelitian ini menjelaskan bahwa ada perbedaan perkembangan bahasa anak prasekolah yang mengikuti dan tidak mengikuti PAUD dengan hasil uji alternatif kolmogorov-sminrov yaitu $p$ value $(0,032)<\alpha(0,05)$. Perbedaan ini menunjukkan kecenderungan semakin baiknya perkembangan bahasa anak yang mengikuti PAUD dibandingkan dengan anak yang tidak mengikuti PAUD. Hal ini didukung dengan hasil penelitian dimana perkembangan bahasa pada kelompok anak prasekolah yang mengikuti PAUD yaitu didominasi dengan perkembangan bahasa yang sesuai sebanyak $65,9 \%$ sedangkan perkembangan bahasa sesuai pada kelompok yang tidak mengikuti PAUD sebanyak 34,1\%. Hasil perkembangan bahasa yang menyimpang hanya ada pada kelompok yang tidak mengikuti PAUD sebesar 22\%. Hasil ini didukung dengan penelitian sebelumnya dimana perkembangan bahasa anak yang mengikuti PAUD hasilnya lebih baik daripada anak yang tidak mengikuti PAUD (Rachmi, Mustika, \& Arifah, 2012).

Perbedaan ini dapat disebabkan oleh beberapa faktor, antara lain lingkungan, usia anak, jenis kelamin, urutan kelahiran dan pendidikan Ibu serta status pekerjaannya Ibu. Faktor lingkungan bisa didapatkan anak dari keluarga, lingkungan belajar dan bermain anak (Liadewi, 2010). Penelitian sebelumnya menyatakan bahwa lingkungan berpengaruh terhadap perkembangan bahasa anak (Candrasari, Eka, Putri, Warraihan, \& Parisa, 2017).
Lingkungan keluarga menjadi salah satu faktor yang dapat memengaruhi perkembangan bahasa anak dan peran dari orangtua di dalam keluarga adalah yang terpenting (Sumaryanti, 2017). Kualitas pemberian stimulasi dari orangtua atau pengasuh yang bisa didapatkan di rumah atau bisa didapatkan di lingkungan bermain dan sekolah adalah faktor yang sangat berpengaruh terhadap perkembangan bahasa anak (Rogers, Nulty, Betancourt, \& DeThome, 2015). Peran pengasuh atau sama halnya dengan guru PAUD di tempat penitipan anak memiliki hubungan yang cukup kuat dalam perkembangan bahasa anak (Krisnana, Rachmawati, \& Sholihah, 2016).

Lingkungan belajar/bermain didalam penelitian ini adalah Pendidikan Anak Usia Dini (PAUD). Lingkungan pertama yang memberikan stimulasi untuk anak adalah keluarga, namun belum tentu setiap keluarga memberikan stimulasi yang maksimal kepada anak untuk menunjang perkembangan bahasa mereka. Stimulasi yang belum terpenuhi tersebut dapat dicapai dengan melibatkan anak pada lingkungan yang mendukung permberian stimulasi tersebut seperti mengikutkan anak di PAUD.

Berdasar faktor usia anak, responden terbanyak pada rentang usia tiga hingga empat tahun, sehingga kategori umur kemudian dipersempit pada usia anak yang sama dengan jumlah terbanyak yaitu usia tiga tahun dan empat tahun. Pada anak usia tiga tahun, di kedua kelompok didominasi dengan perkembangan bahasa yang sesuai sebanyak 25\% di kelompok PAUD dan sebanyak $25,6 \%$ pada kelompok yang tidak PAUD namun pada kelompok ini juga ditemukan terdapat perkembangan bahasa yang menyimpang sebanyak 12,8\% sehingga perkembangan bahasa kelompok PAUD lebih baik dari kelompok tidak 
PAUD. Pada anak usia empat tahun, di kelompok PAUD didominasi dengan perkembangan bahasa yang sesuai sebanyak $46,4 \%$ dan berbeda hasilnya pada kelompok anak yang tidak mengikuti PAUD didominasi dengan perkembangan bahasa yang meragukan sebanyak $17,9 \%$ dengan ditemukan perkembangan bahasa yang menyimpang sebanyak $10,3 \%$ sehingga perkembangan bahasa kelompok PAUD lebih baik dari kelompok tidak PAUD.

Hasil ini didukung dengan penelitian sebelumnya dimana usia anak yang semakin muda maka kemungkinan terjadi keterlambatan perkembangan semakin besar (Ariani \& Yosoprawoto, 2012). Hasil penelitian menunjukkan, anak dengan usia empat tahun pada kelompok PAUD sudah terpapar dengan stimulasi dari lingkungan belajar yaitu PAUD memiliki hasil yang lebih baik dibandingkan dengan usia yang sama pada kelompok yang tidak mengikuti PAUD yang hanya mendapatkan stimulasi dari keluarga saja.

Sebagian besar responden yang mengalami keterlambatan perkembangan bahasa merupakan jenis kelamin laki-laki. Hasil penelitian sebelumnya didapatkan bahwa anak laki-laki lebih banyak mengalami keterlambatan perkembangan bahasa dibandingkan dengan anak perempuan (Hartanto, Selina, \& Fitra, 2011). Selain itu, anak laki-laki cenderung lebih tertinggal dibelakang dalam produksi dan pemahaman kosakata, dalam kompleksitas tata bahasa dan dalam menirukan-menirukan bahasa (Simonsen, Kristoffersen, Bleses, Wehberg, \& Jørgensen, 2013).

Urutan kelahiran penelitian ini menyatakan bahwa anak pertama mendominasi perkembangan bahasa yang sesuai yaitu sebesar 29,3\% pada kelompok PAUD dan $12,2 \%$ pada kelompok yang tidak mengikuti PAUD. Hasil sebuah penelitian menyatakan bahwa keterlambatan bahasa/berbicara pada anak kedua dapat dilihat dari jenis percakapan yang ada dalam keluarga dengan lebih dari satu orang anak dan bagaimana saudara yang lebih tua memengaruhi rutinitas dan interaksi sehari-hari yang dapat membantu untuk perkembangan bicara dan Bahasa (Lowry, 2012).

Faktor lain yang mempengaruhi perkembangan bahasa lainnya adalah pendidikan terakhir Ibu. Hasil penelitian menunjukkan bahwa perkembangan bahasa yang sesuai pada kedua kelompok didominasi pada anak dengan pendidikan Ibu yang tinggi (lulusan SMA/sederajat dan lulusan perguruan tinggi), yaitu sebesar 41,4\% pada kelompok PAUD dan $29,3 \%$ pada kelompok yang tidak mengikuti PAUD. Ibu dengan pendidikan tinggi akan memiliki bekal ilmu yang lebih baik daripada yang memiliki pendidikan rendah. Ibu akan lebih mengerti cara untuk mendidik anak dengan lebih baik, ketika merasakan kejanggalan Ibu akan lebih cepat mengambil tindakan seperti mencari tahu.

Pemberian stimulasi pun berbeda pada status Ibu yang bekerja maupun Ibu rumah tangga. Hasil penelitian ini menyatakan kelompok anak yang mengikuti PAUD, perkembangan bahasa sesuai didominasi pada Ibu yang tidak bekerja sebesar $41,5 \%$ sedangkan pada kelompok yang tidak mengikuti PAUD justru perkembangan bahasa yang sesuai didominasi pada Ibu yang bekerja sebesar $19,5 \%$. Orang tua yang memiliki waktu lebih banyak di rumah bersama anak-anak belum tentu memberikan stimulasi yang cukup dan sesuai dengan usia anak karena stimulus orang tua bergantung pada faktor internal dari orang tua tersebut (Rahmawati \& Sujana, 2016). 
Proses pembelajaran di PAUD sudah terstruktur dan memiliki kurikulum dengan program pengembangan dalam upaya memenuhi perkembangan bahasa anak. Program pengembangan bahasa anak mencakup perwujudan suasana untuk berkembangnya kematangan bahasa dalam konteks bermain. PAUD memiliki program inti yang mendukung perkembangan bahasa anak yaitu menanya, menalar, mencari informasi serta mengkomunikasikan. Selain itu, proses pembelajaran di PAUD memiliki beberapa metode yang mendukung proses perkembangan salah satunya adalah perkembangan bahasa, yaitu: bercerita, demonstrasi, bercakap-cakap, pemberian tugas, sosiodrama/bermain peran, karyawisata, proyek dan eksperimen (Kementerian Pendidikan dan Kebudayaan, 2014). Hal inilah yang menunjang dan mendukung pemberian stimulasi yang lebih baik dengan mengikutkan anak di program Pendidikan Anak Usia Dini.

\section{DAFTAR PUSTAKA}

Ariani, A., \& Yosoprawoto, M. (2012). Usia anak dan pendidikan ibu sebagai faktor risiko gangguan perkembangan anak. Jurnal Kedokteran Brawijaya, 27(2), 118-121.

Browlnie, E., Bao, L., \& Beitchman, J. (2016). Childhood language disorder and social anxiety in early adulthood. Journal of Abnormal Psychology, 44(6), 1061-70. doi: 10.1007/s10802015-0097-5.

Candrasari, A., Eka, D. E., Putri, F., Warraihan \& Parisa, V., (2017). Pengaruh lingkungan terhadap perkembangan. Proceeding of The $5^{\text {th }}$
URECOL, 972-978.

Dhieni, N., Fridani, L., Muis, A., \& Yarmi, G. (2014). Metode pengembangan bahasa. dalam: Hakikat perkembangan bahasa anak (pp. 128). Jakarta: Universitas Terbuka.

Hartanto, F., Selina, H., H, Z., \& Fitra, S. (2011). Pengaruh perkembangan bahasa terhadap perkembangan kognitif anak usia 1-3 tahun. Sari Pediatri, 12(6), 388-389.

Hati, F. S., \& Lestari, P. (2016). Pengaruh pemberian stimulasi pada perkembangan anak usia 12-36 bulan di Kecamatan Sedayu, Bantul. Jurnal Ners dan Kebidanan Indonesia, 4(1), 44. doi: 10.21927/jnki.2016.4(1).4448

Hidayah, N., Prabowo, T., Najmuna, A. (2013). Pola asuh ibu berhubungan dengan tingkat perkembangan bahasa pada anak prasekolah di TK Al Farabi Yogyakarta. Journal Ners and Midwifery Indonesia, 1(2), 48-54.

Kementerian Pendidikan dan Kebudayaan RI (2014). Peraturan Menteri Pendidikan dan Kebudayaan Republik Indonesia Nomor 146 Tahun 2014. Jakarta.

Kementerian Pemberdayaan Perempuan dan Perlindungan Anak. (2015). Profil anak Indonesia 2015. Kementerian Pemberdayaan Perempuan dan Perlindungan Anak \& Badan Pusat Statistik.

Krisnana, I., Rachmawati, P. D., \& Sholihah, M. (2016). Role of care giver stimulation on toddler's language development in day care. Jurnal Ners, 11(2), 240-245. 
Liadewi, V. N. (2010). Asuhan neonates bayi \& anak balita. Jakarta: Salemba Medika.

Lowry, L. (2012). The effect of birth order on emerging language. Diperoleh dari http://www.hanen.org/HelpfulInfo/Professional-Articles/The-Effectof-Birth-Order-on-EmergingLanguage.aspx

Mannani, P. A. (2017). Studi komparasi perkembangan anak pra sekolah yang mengikuti pendidikan anak usia dini (PAUD) dengan anak yang tidak mengikuti. Universitas Diponegoro.

Mulqiah, Z., Santi, E., \& Lestari, D. R. (2017). Pola asuh orang tua dengan perkembangan bahasa anak prasekolah (usia 3-6 tahun ). Dunia Keperawatan, 5(1), 61-67.

Rachmi, N., Mustika, W., \& Arifah, S. (2012). Sosial dan bahasa anak toddler antara yang mengikuti PAUD dan tidak mengikuti PAUD di Kelurahan Nglorog Sragen. Diperoleh dari https://docplayer.info/32675302Perbedaan-perkembangan-motoriksosial-dan-bahasa-anak-toddler.html

Rahmawati, A., \& Sujana, Y. (2016). Status pekerjaan ibu sebagai prediktor kemampuan bahasa lisan anak usia 45 Tahun. Kumara, 1-6. Diperoleh dari http://jurnal.fkip.uns.ac.id/index.php/p aud/article/view/8561

Rogers, C., Nulty, K. L., Betancourt, M. A., \& DeThome, L. S. (2015). Causal effects on child language development: A review of studies in communication sciences and disorders. Journal of Communication Disorders, 57, 3-15.
Simonsen, H. G., Kristoffersen, K. E., Bleses, D., Wehberg, S., \& Jørgensen, R. N. (2013). The Norwegian communicative development inventories: reliability, main developmental trends and gender differences. First Language, 34(1), 3 23. doi: $10.1177 / 0142723713510997$

Soetjiningsih, \& Ranuh, G. (2014). Tumbuh kembang anak. Jakarta: EGC.

Sumaryanti, L. (2017). Peran lingkungan terhadap perkembangan bahasa anak. MUADDIB, 7(1), 72-89.

Tiel, J. M. V. (2007). Anakku terlambat bicara anak berbakat dengan disinkronitas perkembangan, memahami dan mengasuhnya membedakan dengan autisme, ADHD dan permasalahan gangguan belajar. Jakarta: Prenada.

Zaim, A., Mahfuddin, M., Rahmadi, F. A. (2016). Hubungan perkembangan kemampuan bahasa dengan pendidikan anak usia dini nonformal. Jurnal Kedokteran Diponegoro, 5(4), 287-97. Diperoleh dari http://ejournals1.undip.ac.id/index.php/medico. 